\title{
Adherence to Antipsychotic Drugs by Medication Possession Ratio for Schizophrenia and Similar Psychotic Disorders in the Republic of Korea: A Retrospective Cohort Study
}

\author{
Sung Joon Cho \\ Kangbuk Samsung Hospital \\ Jungmee Kim \\ Seoul National University College of Medicine \\ Jin Yong Lee \\ Seoul National University Boramae Medical Center \\ Jee Hoon Sohn ( $\nabla$ eliarde@naver.com ) \\ Seoul National University Department of Architecture and Architectural Engineering \\ https://orcid.org/0000-0001-7206-460X
}

\section{Research article}

Keywords: Psychosis, Schizophrenia, Drug adherence, Medication possession ratio, Pharmacotherapy

Posted Date: August 21st, 2020

DOI: https://doi.org/10.21203/rs.3.rs-59376/v1

License: (1) (1) This work is licensed under a Creative Commons Attribution 4.0 International License. Read Full License 


\section{Abstract}

Background: Pharmacotherapy is considered as an essential element in the treatment of schizophrenia and other psychotic disorders. Discontinuation of antipsychotic drugs increases medical use and economic burden, such as worsening of symptoms, recurrence, and hospitalization. Therefore, maintenance of drug treatment is essential to reduce the social burden caused by schizophrenia and SSP, and hence, it is important to analyze not only the incidence rate of the disorders, but also investigate the rate at which pharmacotherapy is maintained. Therefore, this study aimed to examine the current status of drug compliance using national health insurance data.

Methods: This was a retrospective cohort study, which analyzed data from the nationwide insurance claims database. A total of 343,134 patients who were newly diagnosed with schizophrenia and schizophrenia similar psychosis (SSP) during 2011-2015. The adherence to antipsychotic drugs was assessed by medication possession ratio (MPR) and the risk factors of poor adherence were defined as MPR $<40 \%$.

Results: The average of the MPRs among these patients was $45.8 \%$, and the proportion of patients with less than $40 \%$ of MPR was $50.8 \%$. It was found that female patients, the experience of "psychiatric hospital outpatient," the experience of "psychiatric hospital admission," the experience of "general hospital admission," and patients receiving "medical aid" showed less risk of having statistically significant low $\operatorname{MPR}(<40 \%)$.

Conclusions: In this study, the drug adherence of schizophrenia and SSP patients currently under treatment, as estimated by MPR, was very low. However, it was also found that the MPR was high among patients receiving medical aid, with less medical expenses that they have to pay for themselves. Thus, it is possible to consider an institutional mechanism in which schizophrenia and SSP patients can be treated with less economic burden.

\section{Introduction}

Psychotic disorders, including schizophrenia and schizophrenia similar psychosis (SSP), are among the most serious forms of mental illness with a high prevalence rate. Our previous study, which analyzed data from Korea's Health Insurance Review and Assessment (HIRA) service, reported that the 12-month prevalence of SSP was $0.48-0.66 \%$, and schizophrenia had a 12-month prevalence of $0.40-0.52 \%$ [1]. The annual incidence rate (IR) of SSP reached 118.8-148.7 per 100,000 person-year (PY), and schizophrenia reported an IR of 77.6-88.5 per 100,000.

In the treatment of schizophrenia and SSP, the administration of antipsychotics improves clinical symptoms, and in most cases pharmacotherapy, including antipsychotics, is considered as an essential element in treatment [2-6]. However, in patients with schizophrenia and SSP, it is likely that they will be passive in mental health management due to a lack of insight into their illness and a willingness to discontinue medication [7]. It is known that discontinuation of antipsychotic drugs increases medical use and economic burden, such as worsening of symptoms, recurrence, and hospitalization [8-10]. 
Furthermore, there have been reports that low medication adherence to antipsychotic drugs is associated with decreased functioning and increased relapse in schizophrenic patients [11-13].

Schizophrenia and SSP are typical disorders that place an economic burden on patients, their families, and the society as a whole. According to a report in 2005, direct medical expenses from schizophrenia in the Republic of Korea (hereafter, Korea) alone exceeded 400 million USD (US dollars), and considering socioeconomic costs including unemployment, exceeded 3,000 million USD [14].

Therefore, in order to properly respond to the issue of severe mental illness, it is necessary to understand the exact situation of drug adherence [15-17]. As mentioned above, maintenance of drug treatment is essential to reduce the social burden caused by schizophrenia and SSP, and hence, it is important to analyze not only the incidence rate of the disorders, but also investigate the rate at which pharmacotherapy is maintained. However, due to the nature of mental illness, especially in psychotic disorders, it is not easy to analyze the exact situation because of the difficulties in conducting a complete survey and the diversity in the viewpoints of maintaining treatment [17-19]. Therefore, in this study, the current status of drug compliance was examined using national health insurance data.

\section{Methods}

\section{Data source}

Since 1989, Korea implemented an obligatory universal coverage of medical insurance program, which includes $97 \%$ of the total population registered in the National Health Insurance $(\mathrm{NHI})$, and the remaining $3 \%$ with the lowest socioeconomic status are supported by the National Medical Aid (NMA). The NHI covers almost $97 \%$ of the total population, which was approximately 50 million in 2015 [1]. A government agency, titled, the Health Insurance Review and Assessment Service (HIRA) examines all the claims submitted to the $\mathrm{NHI}$ and NMA for reimbursement. The NHI claims database contains retrospective cohort data on basic information of the patients' sociodemographic characteristics and visits to medical institutions as well as precise information on their diagnoses, prescriptions or diagnostic procedures, and the characteristics of the medical clinics they visited [20]. The methods and structure of the HIRA database have been described elsewhere [21].

\section{Study design and participants}

This was a retrospective cohort study. We estimated the antipsychotic drug adherence of SSP patients and investigated determinants of poor medication adherence using the national health insurance claims data from 2011 to 2015. We defined SSP patients as those who had visited medical institutions with the following diagnostic codes as primary diagnosis: schizophrenia, schizophreniform, acute/transient psychotic disorders, schizoaffective disorders, and other/unspecified nonorganic psychosis (ICD-10 codes: F20, F23, F25, F28, and F29). Our SSP cohort consisted of 343,134 individuals who first visited with the abovementioned diagnoses. Among them, 326,917 patients were prescribed with antipsychotic drugs at least once during 2011-2015, and were included in this study; we studied the level of drug adherence and risk factors for suboptimal adherence. 


\section{Statistical analysis}

SSP patients often change their choice of medical institutions for medication regardless of the size, type, or region of the institution. Therefore, we extracted prescriptions with the maximal days of antipsychotic drug prescribed for each individual and applied the characteristics such as hospital size or hospital visit type (psychiatry outpatient/admission, non-psychiatry outpatient/admission, or day hospital) from those prescriptions. These characteristics of the study population were also applied in the logistic regression model for determinants of suboptimal adherence. Medication adherence was measured by medication possession ratio (MPR) and risk factors were identified by logistic regression analysis, where, an MPR of $40 \%$ or more was set as optimal medication adherence. Instead of proportion of days covered (PDC), MPR was used for calculating medication adherence considering that schizophrenia and SSP patients usually require consistent use of medication over a long period. Long-acting intravenous antipsychotic drugs such

as risperidone, extended-release preparations, or paliperidone palmitate were assumed as it was exposed as many days as the indicated days of use. For example, risperidone and paliperidone palmate were calculated as 14 days and 28 days, respectively. At each episode of hospital admission or within each prescription, there were more than one use of the same product or same class of drugs. Considering the reality where usually different class of drugs are prescribed for extra in need of lack of the main medication effect, we applied the following rules: 1) when different classes of drugs were prescribed on different days within an admission or a prescription, we used the maximal day of any one kind of component as the exposure day of medication, and 2) when the same component drug was prescribed several times within an admission or a prescription, we summed all the prescribed days as the exposure day of medication. The final logistic regression model was verified as adequate with the concordance statistical estimate (c) of 0.64. The SAS Enterprise Guide, version 6.1 (SAS Institute, Inc., Cary, NC, USA) was used for all analyses.

\section{Results}

\section{Antipsychotic drug adherence}

Between 2011 and 2015, a total of 343,134 patients were treated for a diagnosis of schizophrenia or SSP, and 326,917 patients were prescribed antipsychotics, the primary treatment for schizophrenia or SSP, more than once. The average of the MPRs for these patients was $45.8 \%$, and the proportion of patients with an MPR less than $40 \%$ was $50.8 \%$ (Figure 1 ). When the MPR section was analyzed as a $10 \%$ section, a value of $5-6 \%$ was observed, and a group of MPR $90 \%$ or more was analyzed as $21.6 \%$.

The distribution was similar except for patients who were 65 years old, and the distribution of Seoul/Metropolitan/other cities/other provinces was also explored. There were $81.4 \%$ patients covered under the health insurance and $18.6 \%$ patients under medical aid. It was observed that the higher the level of MPR, the higher was the proportion of medical aid patients (Table 1). 
Determinants of suboptimal antipsychotic drug adherence were analyzed by comparing the $\geq 40 \%$ group with the remaining individuals using a multivariable logistic regression model (Table 2).

We found that female patients were associated with the risk of having statistically significant low MPR ( $<$ $40 \%$ ) [OR: $1.010,95 \% \mathrm{Cl}=1.04-1.07, p<.0001]$. Compared with the experience of "psychiatric hospital outpatient," the experience of "psychiatric hospital admission" was associated with the risk of having statistically significant low MPR (< 40\%) [OR: $1.55,95 \% \mathrm{Cl}=1.48-1.62, p<.0001]$, and the experience of "general hospital admission" was associated with the risk of having statistically significant low MPR (< 40\%) [OR: $6.68,95 \% \mathrm{Cl}=6.39-6.98, p<.0001]$. Compared with "being treated in Seoul (the capital city)," "being treated in other metropolitan cities or other cities" was associated with the risk of having statistically significant low MPR (< 40\%) [OR: 1.10, 95\% Cl = 1.08 -1.13, p<.0001; OR: 1.08, 95\% Cl = $1.06-1.11$, $p<.0001]$. "Being treated in rural areas" was not associated with statistically significant low MPR. Finally, compared with "health insurance," "medical aid" was associated with the less risk of having statistically significant low MPR (< 40\%) [OR: 0.92, 95\% Cl = 0.89-0.96, $p<.0001$ ].

\section{Discussion}

The most important element in the treatment of schizophrenia or SSP is pharmacotherapy, and in most cases these disorders require lifelong drug therapy [11]. However, despite the high prevalence of these disorders, it is not easy to determine the extent to which patients maintain drug adherence. Therefore, as an alternative, this study analyzed the MPR of the patients of schizophrenia or SSP as an important index in the treatment of schizophrenia and SSP. In the case of Korea, since, citizens are covered by national health insurance, it was possible to analyze representative data. Several previous studies have analyzed schizophrenia's MPR in different countries. One study was conducted only for Florida Medicaid recipients, and the other study was for the patients who were diagnosed as schizophrenia for the first time in Korea [7-22]. The present study was based on national data for five years to ensure representativeness, and is meaningful in that it is the first study to analyze drug adherence following previous studies of incidence and prevalence studies of schizophrenia and SSP patients [1].

This study is similar to the abovementioned Korean study, but it is very different from the study analyzing the results of Florida in the United States [22]. In this study, the overall MPR was 79\%, and although there was a difference depending on the type of drug, the groups showing $80 \%$ to $100 \%$ of MPR were observed in $62 \%$ to $72 \%$ of the total patient group, and in those showing less than $50 \%$ MPR, the patient group was observed to be $8 \%$ to $15 \%$ depending on the type of drug, which showed a huge difference from the results of Korea. In addition, this result was due to great resistance to medication. In Korea, traditionally, mental illness has been surrounded by stigma $[23,24]$. The fact that the duration of untreated psychosis in Korea is very long compared to other countries also bears out this fact $[25,26]$.

As a result of the analysis of this study, the average value of MPR was only $45.8 \%$, and $50.8 \%$ of patients receiving medication for schizophrenia and SSP were in the MPR group of less than $40 \%$. Since, this study did not include patients who were not admitted to the hospital, were not prescribed antipsychotics, it can be concluded that the drug adherence of schizophrenia and SSP patients in Korea is very low. 
In this study, in the comparative analysis of each MPR group by section, it was found that the higher the MPR group, the higher the proportion of medical aid patients. In addition, the percentage of hospitalization experiences at general hospitals or mental health clinics was reduced, and the average number of days of hospitalization by group was not significantly different around 20 days. This is in line with the analysis of the risk factor of low MPR. Compared to a case where outpatient treatment in a psychiatric hospital occupies the most part of treatment, the experience of hospitalization in a general hospital or a psychiatric hospital was highly correlated with the risk of low MPR $(<40 \%)$.

The major issue observed in this study was that the proportion of patients over 65 years of age was very high. Due to the medical characteristics of the Republic of Korea, diagnostic leniency required to use medications was considered to be attributed to off-label in Korea. Although there was a difference in the figures, the risk factor of low MPR was the same as that of general hospital, mental hospital admission, and outpatient treatment of general hospital. Compared to the capital city, Seoul, similarities were also associated with risk when receiving treatment in six metropolitan and other cities. However, the only difference was that the risk association between health insurance and medical aid patients was not statistically significant.

This study has some limitations. First, since, the study was based on medical insurance claim data, it was difficult to evaluate the contents of clinical conditions of each individual such as the reason of restarting medication or changing the regimen. Second, in this study, drug adherence was estimated with the MPR value, but in fact, possessing a drug may not necessarily mean consuming the drug; hence, this is a conceptual limitation of the study. The overall adherence was critically low even though we used MPR for adherence calculation and added up all the prescribed days. MPR is the sum of the days' supply for all fills of a given drug in a particular time period, divided by the number of days in the time period. Therefore, if an individual refills the medication before the former prescription ends, it can lead to overestimation of adherence. Third, in view of the concept that the drug should be consumed for a lifetime, it may be difficult to conclude that examining only the specific time period determined for this study (2011-2015) accurately reflects the exact drug adherence of a patient. However, this study is meaningful in that it is a study of citizens in one country, and in that it is the first study to investigate drug adherence of schizophrenia and SSP, which require lifelong drug treatment. Even though we did not apply a stricter method of calculation such as PDC, adherence to antipsychotic drugs of SSP patients was found to be low.

\section{Conclusion}

In this study, it can be seen that the drug adherence estimated by MPR of schizophrenia and SSP currently being treated is very low. Considering that the analysis shows that the MPR is high in medical aid patients with low medical expenses that they have to pay for themselves, it is possible to consider an institutional mechanism in which schizophrenia and SSP patients can be treated with less economic burden. In addition, it is considered that future research and continuous attention will be needed for patients who are not receiving adequate treatment

\section{Abbreviations}


Schizophrenia similar psychosis (SSP), Health Insurance Review and Assessment Service (HIRA), incidence rate (IR) person-year (PY), National Health Insurance (NHI), National Medical Aid (NMA), proportion of days covered (PDC), medication possession ratio (MPR).

\section{Declarations}

\section{Ethics approval and consent to participate:}

The study was approved by the Institutional Review Boards of the Seoul National University Hospital with IRB No of 1705-106-855.

\section{Consent for publication:}

Not applicable.

\section{Availability of data and materials:}

The datasets generated and/or analysed during the current study are not publicly available due to policy of Health Insurance Review and Assessment Service but are available from the corresponding author on reasonable request.

\section{Competing interests}

The authors declare that they have no competing interests.

\section{Funding:}

There was no research grant directly associated to this study.

\section{Authors' contributions:}

Conceptualization: Jin Yong Lee, Jee Hoon Sohn. Data curation: Jungmee Kim. Investigation: Sung Joon Cho. Methodology: Jungmee Kim, Jin Yong Lee. Project administration: Jee Hoon Sohn. Supervision: Jin Yong Lee, Jee Hoon Sohn. Validation: Sung Joon Cho. Writing: Sung Joon Cho, Jungmee Kim, Jee Hoon Sohn, Jin Yong Lee.

\section{Acknowledgements:}

The idea of study was inspired during the analysis for development of mental health policy of Seoul. We hereby thanks to all staffs of Seoul Mental Health Center and Health Policy Division of Seoul Metropolitan Government for their enthusiasm and contribution for the betterment of mental health in Seoul.

\section{Reference}

1. Cho SJ, Kim J, Kang YJ, Lee SY, Seo HY, Park JE, et al. Annual Prevalence and Incidence of Schizophrenia and Similar Psychotic Disorders in the Republic of Korea: A National Health Insurance 
Data-Based Study. Psychiatry Investigation. 2020;17(1):61.

2. Kane JM, Marder SR. Psychopharmacologic treatment of schizophrenia. Schizophrenia bulletin. 1993;19(2):287-302.

3. Dixon LB, Lehman AF, Levine J. Conventional antipsychotic medications for schizophrenia. Schizophrenia bulletin. 1995;21(4):567-77.

4. Leucht S, Tardy M, Komossa K, Heres S, Kissling W, Salanti G, et al. Antipsychotic drugs versus placebo for relapse prevention in schizophrenia: a systematic review and meta-analysis. The Lancet. 2012;379(9831):2063-71.

5. Tiihonen J, Walhbeck K, Lönnqvist J, Klaukka T, loannidis JP, Volavka J, et al. Effectiveness of antipsychotic treatments in a nationwide cohort of patients in community care after first hospitalisation due to schizophrenia and schizoaffective disorder: observational follow-up study. Bmj. 2006;333(7561):224.

6. Geddes J, Freemantle N, Harrison P, Bebbington P. Atypical antipsychotics in the treatment of schizophrenia: systematic overview and meta-regression analysis. Bmj. 2000;321(7273):1371-6.

7. Heo JU, Kim DW, Oh S-T, Choi W-J, Park J. Clinical Characteristics, Drug Adherence to Antipsychotics and Medical Use Trends in Patients First Diagnosed with Psychotic Disorder: A Preliminary Study. Korean Journal of Schizophrenia Research. 2019;22(2):42-50.

8. Weiden PJ, Olfson M. Cost of relapse in schizophrenia. Schizophrenia bulletin. 1995;21(3):419-29.

9. Valenstein M, Copeland LA, Blow FC, McCarthy JF, Zeber JE, Gillon L, et al. Pharmacy data identify poorly adherent patients with schizophrenia at increased risk for admission. Medical care. 2002:630-9.

10. Terkelsen KC, Menikoff A. Measuring the costs of schizophrenia. Pharmacoeconomics. 1995;8(3):199222.

11. Bellack AS, Bowden CL, Bowie CR, Byerly MJ, Carpenter WT, Copeland LA, et al. The expert consensus guideline series: adherence problems in patients with serious and persistent mental illness. Journal of clinical psychiatry. 2009;70(SUPPL. 4):1-48.

12. Morken G, Widen JH, Grawe RW. Non-adherence to antipsychotic medication, relapse and rehospitalisation in recent-onset schizophrenia. BMC psychiatry. 2008;8(1):32.

13. Casey DE. Metabolic issues and cardiovascular disease in patients with psychiatric disorders. The American Journal of Medicine Supplements. 2005;118:15-22.

14. Chang SM, Cho S-J, Jeon HJ, Hahm B-J, Lee HJ, Park J-I, et al. Economic burden of schizophrenia in South Korea. Journal of Korean medical science. 2008;23(2):167-75.

15. van Os J, Kapur S. Schizophrenia. Lancet Lond. Engl. 374, 635-645. 2009.

16. CHIEN IC, CHOU YJ, LIN CH, BIH SH, Chou P, CHANG HJ. Prevalence and incidence of schizophrenia among national health insurance enrollees in Taiwan, 1996-2001. Psychiatry and clinical Neurosciences. 2004;58(6):611-8.

17. Wu EQ, Shi L, Birnbaum H, Hudson T, Kessler R. Annual prevalence of diagnosed schizophrenia in the USA: a claims data analysis approach. Psychological Medicine. 2006;36(11):1535. 
18. Cho MJ, Seong SJ, Park JE, Chung I-W, Lee YM, Bae A, et al. Prevalence and correlates of DSM-IV mental disorders in South Korean adults: the Korean epidemiologic catchment area study 2011. Psychiatry investigation. 2015;12(2):164.

19. Hong J, Lee D, Ham B, Lee S, Sung S, Yoon T. The survey of mental disorders in Korea 2016. Seoul: Ministry of Health and Welfare. 2017.

20. Kim J, Lee E, Park B-J, Bang JH, Lee JY. Adherence to antiretroviral therapy and factors affecting low medication adherence among incident HIV-infected individuals during 2009-2016: a nationwide study. Scientific reports. 2018;8(1):1-8.

21. Kim J, Yoon S, Kim L-Y, Kim D-S. Towards actualizing the value potential of Korea Health Insurance Review and Assessment (HIRA) data as a resource for health research: strengths, limitations, applications, and strategies for optimal use of HIRA data. Journal of Korean medical science. 2017;32(5):718-28.

22. Lang K, Meyers JL, Korn JR, Lee S, Sikirica M, Crivera C, et al. Medication adherence and hospitalization among patients with schizophrenia treated with antipsychotics. Psychiatric services. 2010;61(12):1239-47.

23. Park J-I, Jeon M. The stigma of mental illness in Korea. Journal of Korean Neuropsychiatric Association. 2016;55(4):299-309.

24. Kim J, Seo M. Comparing prejudice and discrimination according to types of mental disorder. Mental Health \& Social Work. 2011;37:35-64.

25. Jeon D-I, Lee S-H, Gong J-E. Clinical correlates of duration of untreated psychosis in patients with schizophrenia. Journal of Korean Neuropsychiatric Association. 2004;43(4):401-6.

26. Chon M-W, Lee TY, Kim SN, Huh MJ, Park HY, Lee CR, et al. Factors contributing to the duration of untreated prodromal positive symptoms in individuals at ultra-high risk for psychosis. Schizophrenia Research. 2015;162(1-3):64-6.

\section{Tables}

Table 1. Characteristics of newly diagnosed patients with schizophrenia and schizophrenia-similar disorders by antipsychotic drugs medication possession ratio (MPR) during 2011-2015 ( $\mathrm{n=326} 917$ ) 


\begin{tabular}{|c|c|c|c|c|c|c|c|}
\hline $\mathrm{N}(\%)$ & $\begin{array}{l}<5 \% \\
\text { MPR }\end{array}$ & $\begin{array}{l}5-20 \% \\
\text { MPR }\end{array}$ & $\begin{array}{l}20-40 \% \\
\text { MPR }\end{array}$ & $\begin{array}{l}40-60 \% \\
\text { MPR }\end{array}$ & $\begin{array}{l}60-80 \% \\
\text { MPR }\end{array}$ & $\begin{array}{l}80-95 \% \\
\text { MPR }\end{array}$ & $95 \% \leq \mathrm{MPR}$ \\
\hline Total & $\begin{array}{l}59484 \\
(18.2)\end{array}$ & $\begin{array}{l}60870 \\
(18.6)\end{array}$ & $\begin{array}{l}45669 \\
(14.0)\end{array}$ & $\begin{array}{l}36113 \\
(11.0)\end{array}$ & $\begin{array}{l}34712 \\
(10.6)\end{array}$ & $\begin{array}{l}32005 \\
(9.8)\end{array}$ & $\begin{array}{l}58064 \\
(17.8)\end{array}$ \\
\hline \multicolumn{8}{|l|}{ Gender } \\
\hline Men & $\begin{array}{l}29285 \\
(49.2)\end{array}$ & $\begin{array}{l}29183 \\
(47.9)\end{array}$ & $\begin{array}{l}21389 \\
(46.8)\end{array}$ & $\begin{array}{l}16360 \\
(45.3)\end{array}$ & $\begin{array}{l}15511 \\
(44.7)\end{array}$ & $\begin{array}{l}14518 \\
(45.4)\end{array}$ & $\begin{array}{l}26151 \\
(45.0)\end{array}$ \\
\hline Women & $\begin{array}{l}30199 \\
(50.8)\end{array}$ & $\begin{array}{l}31687 \\
(52.1)\end{array}$ & $\begin{array}{l}24280 \\
(53.2)\end{array}$ & $\begin{array}{l}19753 \\
(54.7)\end{array}$ & $\begin{array}{l}19201 \\
(55.3)\end{array}$ & $\begin{array}{l}17487 \\
(54.6)\end{array}$ & $\begin{array}{l}31913 \\
(55.0)\end{array}$ \\
\hline \multicolumn{8}{|l|}{ Age group } \\
\hline$<15$ & $3(0.0)$ & $4(0.0)$ & $2(0.0)$ & $0(0.0)$ & $0(0.0)$ & $0(0.0)$ & $2(0.0)$ \\
\hline $15-24$ & $\begin{array}{l}3651 \\
(6.1)\end{array}$ & $\begin{array}{l}4493 \\
(7.4)\end{array}$ & $\begin{array}{l}3736 \\
(8.2)\end{array}$ & $\begin{array}{l}3183 \\
(8.8)\end{array}$ & $\begin{array}{l}3399 \\
(9.8)\end{array}$ & $\begin{array}{l}3556 \\
(11.1)\end{array}$ & $\begin{array}{l}5530 \\
(9.5)\end{array}$ \\
\hline $25-34$ & $\begin{array}{l}5216 \\
(8.8)\end{array}$ & $\begin{array}{l}6038 \\
(9.9)\end{array}$ & $\begin{array}{l}4639 \\
(10.2)\end{array}$ & $\begin{array}{l}3934 \\
(10.9)\end{array}$ & $\begin{array}{l}4233 \\
(12.2)\end{array}$ & $\begin{array}{l}3910 \\
(12.2)\end{array}$ & $\begin{array}{l}6281 \\
(10.8)\end{array}$ \\
\hline $35-44$ & $\begin{array}{l}6700 \\
(11.3)\end{array}$ & $\begin{array}{l}7017 \\
(11.5)\end{array}$ & $\begin{array}{l}5367 \\
(11.8)\end{array}$ & $\begin{array}{l}4540 \\
(12.6)\end{array}$ & $\begin{array}{l}4565 \\
(13.2)\end{array}$ & $\begin{array}{l}4596 \\
(14.4)\end{array}$ & $\begin{array}{l}7879 \\
(13.6)\end{array}$ \\
\hline $45-54$ & $\begin{array}{l}8717 \\
(14.7)\end{array}$ & $\begin{array}{l}8552 \\
(14.0)\end{array}$ & $\begin{array}{l}6374 \\
(14.0)\end{array}$ & $\begin{array}{l}5105 \\
(14.1)\end{array}$ & $\begin{array}{l}5121 \\
(14.8)\end{array}$ & $\begin{array}{l}5122 \\
(16.0)\end{array}$ & $\begin{array}{l}9100 \\
(15.7)\end{array}$ \\
\hline $55-64$ & $\begin{array}{l}8331 \\
(14.0)\end{array}$ & $\begin{array}{l}8028 \\
(13.2)\end{array}$ & $\begin{array}{l}5823 \\
(12.8)\end{array}$ & $\begin{array}{l}4608 \\
(12.8)\end{array}$ & $\begin{array}{l}4478 \\
(12.9)\end{array}$ & $\begin{array}{l}4296 \\
(13.4)\end{array}$ & $\begin{array}{l}8055 \\
(13.9)\end{array}$ \\
\hline $65 \leq$ & $\begin{array}{l}28866 \\
(45.2)\end{array}$ & $\begin{array}{l}26738 \\
(43.9)\end{array}$ & $\begin{array}{l}19728 \\
(43.2)\end{array}$ & $\begin{array}{l}14473 \\
(40.8)\end{array}$ & $\begin{array}{l}12916 \\
(37.2)\end{array}$ & $\begin{array}{l}10525 \\
(32.9)\end{array}$ & $\begin{array}{l}21217 \\
(36.5)\end{array}$ \\
\hline \multicolumn{8}{|l|}{$\begin{array}{l}\text { Type of } \\
\text { medical } \\
\text { institution }\end{array}$} \\
\hline $\begin{array}{c}\text { Tertiary } \\
\text { hospital }\end{array}$ & $\begin{array}{l}12647 \\
(21.3)\end{array}$ & $\begin{array}{l}11204 \\
(18.4)\end{array}$ & $\begin{array}{l}7454 \\
(16.3)\end{array}$ & $\begin{array}{l}5621 \\
(15.6)\end{array}$ & $\begin{array}{l}5422 \\
(15.6)\end{array}$ & $\begin{array}{l}4945 \\
(15.5)\end{array}$ & $\begin{array}{l}10728 \\
(18.5)\end{array}$ \\
\hline $\begin{array}{l}\text { General } \\
\text { Hospital }\end{array}$ & $\begin{array}{l}18214 \\
(30.6)\end{array}$ & $\begin{array}{l}16418 \\
(27.0)\end{array}$ & $\begin{array}{l}11213 \\
(24.6)\end{array}$ & $\begin{array}{l}8382 \\
(23.2)\end{array}$ & $\begin{array}{l}7808 \\
(22.5)\end{array}$ & $\begin{array}{l}6651 \\
(20.8)\end{array}$ & $\begin{array}{l}14427 \\
(24.8)\end{array}$ \\
\hline Hospital & $\begin{array}{l}11876 \\
(20.0)\end{array}$ & $\begin{array}{l}14283 \\
(23.5)\end{array}$ & $\begin{array}{l}11745 \\
(25.7)\end{array}$ & $\begin{array}{l}9579 \\
(26.5)\end{array}$ & $\begin{array}{l}9572 \\
(27.6)\end{array}$ & $\begin{array}{l}9452 \\
(29.5)\end{array}$ & $\begin{array}{l}15261 \\
(26.3)\end{array}$ \\
\hline Clinic & $\begin{array}{l}14887 \\
(25.0)\end{array}$ & $\begin{array}{l}16613 \\
(27.3)\end{array}$ & $\begin{array}{l}13.413 \\
(29.4)\end{array}$ & $\begin{array}{l}11068 \\
(30.6)\end{array}$ & $\begin{array}{l}10610 \\
(30.6)\end{array}$ & $\begin{array}{l}9816 \\
(30.7)\end{array}$ & $\begin{array}{l}15896 \\
(27.4)\end{array}$ \\
\hline $\begin{array}{l}\text { Nursing } \\
\text { hospital }\end{array}$ & $\begin{array}{l}1845 \\
(3.1)\end{array}$ & $\begin{array}{l}2317 \\
(3.8)\end{array}$ & $\begin{array}{l}1797 \\
(3.9)\end{array}$ & $\begin{array}{l}1431 \\
(4.0)\end{array}$ & $\begin{array}{l}1269 \\
(3.7)\end{array}$ & $\begin{array}{l}1101 \\
(3.4)\end{array}$ & $\begin{array}{l}1705 \\
(2.9)\end{array}$ \\
\hline Public clinic & $15(0.0)$ & $35(0.1)$ & $47(0.1)$ & $32(0.1)$ & $31(0.1)$ & $40(0.1)$ & $47(0.1)$ \\
\hline
\end{tabular}


hospital visit

\begin{tabular}{|c|c|c|c|c|c|c|c|}
\hline $\begin{array}{l}\text { Hospital } \\
\text { outpatient }\end{array}$ & $\begin{array}{l}30387 \\
(51.1)\end{array}$ & $\begin{array}{l}39069 \\
(64.2)\end{array}$ & $\begin{array}{l}32376 \\
(70.9)\end{array}$ & $\begin{array}{l}26189 \\
(72.5)\end{array}$ & $\begin{array}{l}25153 \\
(72.5)\end{array}$ & $\begin{array}{l}22480 \\
(70.2)\end{array}$ & $\begin{array}{l}41864 \\
(72.1)\end{array}$ \\
\hline $\begin{array}{l}\text { Hospital } \\
\text { admission }\end{array}$ & $\begin{array}{l}25637 \\
(43.1)\end{array}$ & $\begin{array}{l}16098 \\
(26.4)\end{array}$ & $\begin{array}{l}7434 \\
(16.3)\end{array}$ & $\begin{array}{l}4558 \\
(12.6)\end{array}$ & $\begin{array}{l}3661 \\
(10.5)\end{array}$ & $\begin{array}{l}3190 \\
(10.0)\end{array}$ & $\begin{array}{l}3942 \\
(6.8)\end{array}$ \\
\hline Public clinic & $3(0.0)$ & $17(0.0)$ & $16(0.0)$ & $15(0.0)$ & $19(0.1)$ & $17(0.1)$ & $24(0.0)$ \\
\hline $\begin{array}{l}\text { Psychiatry } \\
\text { outpatient }\end{array}$ & $\begin{array}{l}2326 \\
(3.9)\end{array}$ & $\begin{array}{l}3801 \\
(6.2)\end{array}$ & $\begin{array}{l}3968 \\
(8.7)\end{array}$ & $\begin{array}{l}3757 \\
(10.4)\end{array}$ & $\begin{array}{l}4146 \\
(11.9)\end{array}$ & $\begin{array}{l}4316 \\
(13.5)\end{array}$ & $\begin{array}{l}9060 \\
(15.6)\end{array}$ \\
\hline $\begin{array}{l}\text { Psychiatry } \\
\text { admission }\end{array}$ & $\begin{array}{l}1129 \\
(1.9)\end{array}$ & $\begin{array}{l}1880 \\
(3.1)\end{array}$ & $\begin{array}{l}1868 \\
(4.1)\end{array}$ & $\begin{array}{l}1584 \\
(4.4)\end{array}$ & $\begin{array}{l}1718 \\
(4.9)\end{array}$ & $\begin{array}{l}1976 \\
(6.2)\end{array}$ & $\begin{array}{l}3135 \\
(5.4)\end{array}$ \\
\hline $\begin{array}{l}\text { Psychiatry } \\
\text { ward }\end{array}$ & $2(0.0)$ & $5(0.0)$ & $7(0.0)$ & $10(0.0)$ & $15(0.0)$ & $26(0.1)$ & $39(0.1)$ \\
\hline $\begin{array}{l}\text { Total } \\
\text { hospital } \\
\text { days (mean, } \\
\text { SD)* }\end{array}$ & $\begin{array}{l}1169 \\
(2800.0)\end{array}$ & $\begin{array}{l}4261 \\
(8461.9)\end{array}$ & $\begin{array}{l}10553 \\
(19041.0)\end{array}$ & $\begin{array}{l}18103 \\
(60422.9)\end{array}$ & $\begin{array}{l}26901 \\
(47127.0)\end{array}$ & $\begin{array}{l}37986 \\
(74184.4)\end{array}$ & $\begin{array}{l}35568 \\
(83237.0)\end{array}$ \\
\hline $\begin{array}{l}\text { Maximal } \\
\text { hospital } \\
\text { days (mean, } \\
\text { SD) }\end{array}$ & $\begin{array}{l}18 \\
(16.4)\end{array}$ & $\begin{array}{l}20 \\
(17.3)\end{array}$ & 21 (17.3) & $21(17.4)$ & $21(17.7)$ & 21 (17.9) & 18 (16.1) \\
\hline
\end{tabular}

\section{Region of \\ medical \\ institution}

\begin{tabular}{|c|c|c|c|c|c|c|c|}
\hline $\begin{array}{l}\text { Seoul } \\
\text { (capital city) }\end{array}$ & $\begin{array}{l}12487 \\
(21.0)\end{array}$ & $\begin{array}{l}13781 \\
(22.6)\end{array}$ & $\begin{array}{l}10150 \\
(22.2)\end{array}$ & $\begin{array}{l}7917 \\
(21.9)\end{array}$ & $\begin{array}{l}7593 \\
(21.9)\end{array}$ & $\begin{array}{l}6942 \\
(21.7)\end{array}$ & $\begin{array}{l}13745 \\
(23.7)\end{array}$ \\
\hline $\begin{array}{l}6 \\
\text { metropolitan } \\
\text { cities }\end{array}$ & $\begin{array}{l}17243 \\
(29.0)\end{array}$ & $\begin{array}{l}15935 \\
(26.2)\end{array}$ & $\begin{array}{l}11888 \\
(26.0)\end{array}$ & $\begin{array}{l}9475 \\
(26.2)\end{array}$ & $\begin{array}{l}9348 \\
(26.9)\end{array}$ & $\begin{array}{l}8507 \\
(26.6)\end{array}$ & $\begin{array}{l}14512 \\
(25.0)\end{array}$ \\
\hline Other cities & $\begin{array}{l}14874 \\
(25.0)\end{array}$ & $\begin{array}{l}15383 \\
(25.3)\end{array}$ & $\begin{array}{l}11549 \\
(25.3)\end{array}$ & $\begin{array}{l}9228 \\
(25.6)\end{array}$ & $\begin{array}{l}8847 \\
(25.5)\end{array}$ & $\begin{array}{l}7994 \\
(25.0)\end{array}$ & $\begin{array}{l}14405 \\
(24.8)\end{array}$ \\
\hline Rural area & $\begin{array}{l}14880 \\
(25.0)\end{array}$ & $\begin{array}{l}15766 \\
(25.9)\end{array}$ & $\begin{array}{l}12082 \\
(26.5)\end{array}$ & $\begin{array}{l}9493 \\
(26.3)\end{array}$ & $\begin{array}{l}8924 \\
(25.7)\end{array}$ & $\begin{array}{l}8562 \\
(26.8)\end{array}$ & $\begin{array}{l}15402 \\
(26.5)\end{array}$ \\
\hline \multicolumn{8}{|l|}{$\begin{array}{l}\text { Type of } \\
\text { medical } \\
\text { coverage }\end{array}$} \\
\hline $\begin{array}{l}\text { Health } \\
\text { insurance }\end{array}$ & $\begin{array}{l}51982 \\
(87.4)\end{array}$ & $\begin{array}{l}51853 \\
(85.2)\end{array}$ & $\begin{array}{l}37610 \\
(82.4)\end{array}$ & $\begin{array}{l}29072 \\
(80.5)\end{array}$ & $\begin{array}{l}27508 \\
(79.2)\end{array}$ & $\begin{array}{l}24606 \\
(76.9)\end{array}$ & $\begin{array}{l}43338 \\
(74.6)\end{array}$ \\
\hline Medical aid & $\begin{array}{l}7502 \\
(12.6)\end{array}$ & $\begin{array}{l}9017 \\
(14.8)\end{array}$ & $\begin{array}{l}8059 \\
(17.6)\end{array}$ & $\begin{array}{l}7041 \\
(19.5)\end{array}$ & $\begin{array}{l}7204 \\
(20.8)\end{array}$ & $\begin{array}{l}7399 \\
(23.1)\end{array}$ & $\begin{array}{l}14726 \\
(25.4)\end{array}$ \\
\hline
\end{tabular}

*Total hospital days with antipsychotic drugs prescription 
Table 2. Risk factors for suboptimal adherence to antipsychotic drugs among patients with schizophrenia and schizophrenia-similar disorders during 2011-2015 ( $n=326,917)$ 


\begin{tabular}{|c|c|c|c|c|}
\hline & $\mathrm{N}(\%)$ & $\begin{array}{l}\text { Unadjusted OR } \\
(95 \% \mathrm{Cl})\end{array}$ & $\begin{array}{l}\text { Adjusted OR (95\% } \\
\text { Cl) })^{\star}\end{array}$ & $\begin{array}{l}P \text { (for adjusted } \\
\text { OR) }\end{array}$ \\
\hline \multicolumn{5}{|l|}{ Gender } \\
\hline Men & $\begin{array}{l}152397 \\
(46.6)\end{array}$ & - & - & \\
\hline Women & $\begin{array}{l}174520 \\
(35.4)\end{array}$ & $1.13(1.11-1.14)$ & $1.10(1.04-1.07)$ & $<.0001$ \\
\hline \multicolumn{5}{|l|}{ Age group } \\
\hline$<15$ & $11(0.0)$ & - & - & \\
\hline $15-24$ & $\begin{array}{l}27548 \\
(8.4)\end{array}$ & $0.17(0.04-0.79)$ & $0.17(0.04-0.79)$ & 0.02 \\
\hline $25-34$ & $\begin{array}{l}34251 \\
(10.5)\end{array}$ & $0.20(0.04-0.90)$ & $0.19(0.04-0.89)$ & 0.04 \\
\hline $35-44$ & $\begin{array}{l}40664 \\
(12.4)\end{array}$ & $0.20(0.04-0.92)$ & $0.20(0.04-0.95)$ & 0.04 \\
\hline $45-54$ & $\begin{array}{l}48091 \\
(14.7)\end{array}$ & $0.22(0.05-1.00)$ & $0.22(0.05-1.04)$ & 0.06 \\
\hline $55-64$ & $\begin{array}{l}43619 \\
(13.3)\end{array}$ & $0.23(0.05-1.07)$ & $0.22(0.05-1.02)$ & 0.05 \\
\hline $65 \leq$ & $\begin{array}{l}132733 \\
(40.6)\end{array}$ & $0.28(0.06-1.28)$ & $0.24(0.05-1.10)$ & 0.07 \\
\hline \multicolumn{5}{|l|}{$\begin{array}{l}\text { Type of medical } \\
\text { institution }\end{array}$} \\
\hline Tertiary hospital & $\begin{array}{l}85021 \\
(17.7)\end{array}$ & - & - & \\
\hline General Hospital & $\begin{array}{l}83113 \\
(25.4)\end{array}$ & $1.05(1.03-1.07)$ & $1.01(0.99-1.04)$ & 0.3 \\
\hline Hospital & $\begin{array}{l}81768 \\
(25.0)\end{array}$ & $0.74(0.72-0.75)$ & $0.68(0.66-0.70)$ & $<.0001$ \\
\hline Clinic & $\begin{array}{l}92203 \\
(28.2)\end{array}$ & $0.81(0.79-0.83)$ & $1.10(1.08-1.13)$ & $<.0001$ \\
\hline Nursing hospital & $\begin{array}{l}11465 \\
(3.5)\end{array}$ & $0.92(0.89-0.96)$ & $0.77(0.74-0.81)$ & $<.0001$ \\
\hline Public clinic & $247(0.1)$ & $0.55(0.43-0.71)$ & $0.89(0.63-1.25)$ & 0.5 \\
\hline \multicolumn{5}{|l|}{ Type of hospital visit } \\
\hline Hospital outpatient & $\begin{array}{l}217518 \\
(66.5)\end{array}$ & $1.86(1.81-1.90)$ & $1.69(1.62-1.76)$ & $<.0001$ \\
\hline Hospital admission & 64520 & $6.75(6.55-6.96)$ & $6.68(6.39-6.98)$ & $<.0001$ \\
\hline
\end{tabular}




\begin{tabular}{|lllll|}
\hline Public clinic & $111(0.0)$ & $1.01(0.68-1.51)$ & $0.97(0.57-1.64)$ & 0.9 \\
\hline Psychiatry outpatient & $\begin{array}{l}31374 \\
(9.6)\end{array}$ & - & - & \\
\hline Psychiatry admission & $\begin{array}{l}13290 \\
(4.1)\end{array}$ & $1.22(1.17-1.28)$ & $1.55(1.48-1.62)$ & $<.0001$ \\
\hline Psychiatry ward & $104(0.0)$ & $0.33(0.19-0.58)$ & $0.40(0.23-0.70)$ & 0.001 \\
\hline $\begin{array}{l}\text { Region of medical } \\
\text { institution }\end{array}$ & & & & \\
\hline Seoul (capital city) & $\begin{array}{l}72615 \\
(22.2)\end{array}$ & - & - & \\
\hline 6 metropolitan cities & $\begin{array}{l}86908 \\
(26.6)\end{array}$ & $1.07(1.05-1.09)$ & $1.10(1.08-1.13)$ & $<.0001$ \\
\hline Other cities & $\begin{array}{l}82285 \\
(25.2)\end{array}$ & $1.03(1.011-1.05)$ & $1.08(1.06-1.11)$ & $<.0001$ \\
\hline Rural area & $\begin{array}{l}85109 \\
(26.0)\end{array}$ & $1.00(0.98-1.02)$ & $1.02(1.00-1.04)$ & 0.1 \\
\hline $\begin{array}{l}\text { Type of medical } \\
\text { coverage }\end{array}$ & & & & \\
\hline Health insurance & $\begin{array}{l}265969 \\
(81.4)\end{array}$ & - & & \\
\hline Medical aid & $\begin{array}{l}\text { 60948 } \\
(18.6)\end{array}$ & $0.60(0.58-0.61)$ & $0.92(0.89-0.96)$ & $<.0001$ \\
\hline
\end{tabular}

*Adjusted for all the information in the table

\section{Figures}




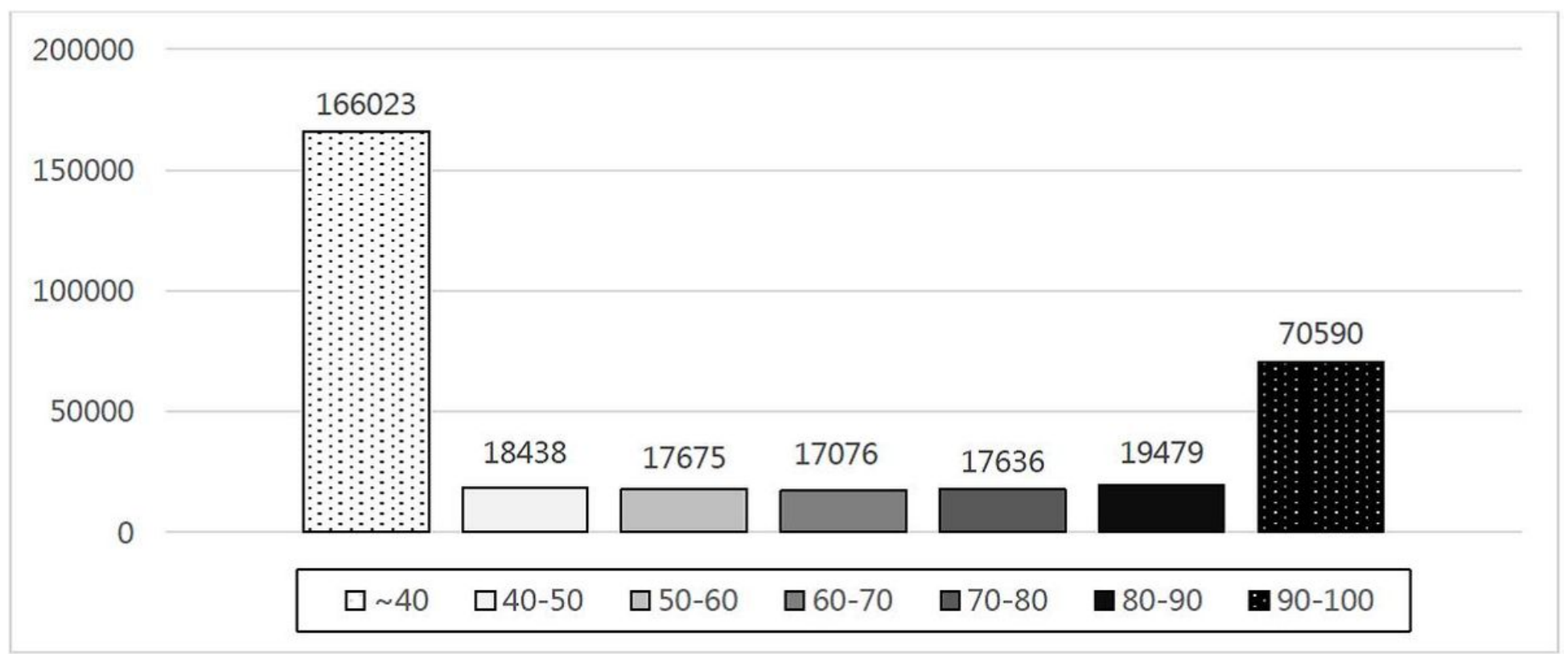

Figure 1

Number of patients divided by adherence to antipsychotic drugs by medication possession ratio for schizophrenia and similar psychotic disorders in Republic of Korea. 